\title{
PENGGUNAAN JURNAL BELAJAR DALAM PEMBELAJARAN CLASS WIDE PEER TUTORING TERHADAP KEMAMPUAN BERPIKIR KRITIS SISWA
}

\author{
Lailatul Munawaroh $^{1}$, Yuni Pantiwati' ${ }^{2}$, Ainur Rofieq ${ }^{2}$ \\ ${ }^{1}$ Alumni Pendidikan Biologi FKIP Universtias Muhammadiyah Malang \\ ${ }^{2}$ Pendidikan Biologi FKIP Universtias Muhammadiyah Malang \\ e-mail: yuni_pantiwati@yahoo.co.id
}

\begin{abstract}
ABSTRAK
Standar asesmen pembelajaran sains hendaknya ditekankan pada penilaian kemampuan siswa dalam real life situation. Diperlukan adanya sistem penilaian untuk mengatasi masalah tersebut. Penggunaan jurnal belajar sebagai refleksi setelah proses pembelajaran menjadi alternatif untuk melatih cara berpikir siswa yang dipadukan dengan pembelajaran Class Wide Peer Tutoring agar siswa lebih aktif. Tujuan penelitian ini untuk menganalisis pengaruh penggunaan jurnal belajar dalam pembelajaran Class Wide Peer Tutoring untuk meningkatkan kemampuan berpikir kritis siswa, mendeskripsikan penerapan jurnal belajar dalam pembelajaran Class Wide Peer Tutoring mempengaruhi peningkatan kemampuan berpikir kritis, dan mendeskripsikan peningkatan kemampuan berpikir kritis setelah perlakuan penggunaan jurnal belajar dalam pembelajaran Class Wide Peer Tutoring. Penelitian dilaksanakan di SMP Muhammadiyah di Kabupaten Malang kelas VIII. Jenis penelitian ini adalah Quasy Eksperimen dengan teknik pengambilan Cluster Random Sampling. Penelitian dilaksanakan di SMP Muhammadiyah di Kabupaten Malang. Data kemampuan berpikir kritis diperoleh dengan test soal esay. Analisis data yang digunakan yaitu uji Independent t-tes. Hasil penelitian menunjukkan penggunaan jurnal belajar dalam pembelajaran Class Wide Peer Tutoring memiliki pengaruh terhadap kemampuan berpikir kritis materi fotosintesis pada siswa kelas VIII SMP Muhammadiyah di Kabupaten Malang. Penerapan penggunaan jurnal belajar dilakukan setelah proses pembelajaran. Peningkatan kemampuan berpikir kritis lebih efektif terjadi pada kelompok eksperimen daripada kontrol.
\end{abstract}

Kata Kunci: berpikir kritis, hasil belajar, kooperatif, pembelajaran CIRC

Jurnal belajar adalah dokumen tertulis yang dibuat siswa dan berisi refleksi setelah mengalami proses belajar. Jurnal belajar berpotensi meningkatkan pembelajaran dengan melalui proses menulis dan berpikir tentang pengalaman belajar, bersifat pribadi dan dapat digunakan untuk merefleksi diri. Menulis jurnal belajar dapat mengarahkan pada pembelajaran yang lebih baik karena merupakan sesuatu yang konstruktif dan melibatkan proses reflektif (Kartono \& Imron, 2010).

Jurnal belajar membuat guru dapat menilai seberapa dalam pemahaman siswa terhadap materi yang baru dipelajari, sekaligus mengoreksi kelemahan dan kesalahan siswa. Jurnal belajar juga melatih cara berpikir siswa dalam meningkatkan prestasi belajarnya (Junaedi, 2013).
Jurnal belajar ini diharapkan tidak ada siswa yang hanya diam di kelas ketika pembelajaran. Adanya jurnal belajar dapat memantau apa yang dilakukan siswa ketika pembelajaran dan sebagai alat ukur untuk mengetahui tingkat keaktifan siswa dalam pembelajaran meskipun tidak mengawasi siswa satu-persatu siswa. Guru tidak hanya mengukur kemampuan siswa berdasarkan hasil ujian tetapi juga meliputi keaktifan siswa itu dalam kelas (Sutrisno, 2010).

Keuntungan lain penggunaan jurnal belajar yaitu dapat memungkinkan siswa lebih sadar akan belajarnya dan mengungkapkan apa yang ada di benak siswa. Penggunaan jurnal belajar dalam pembelajaran Biologi pernah diterapkan dalam penelitian lain. Hasil yang diperoleh menunjukkan adanya peningkatan kualitas pembelajaran menggunakan macromedia 
flash sebagai media dalam pembelajaran yang dilaksanakan. Hal ini dapat dilihat dari peningkatan motivasi belajar dan partisipasi siswa yang berdampak pada peningkatan penguasaan konsep. Peningkatan motivasi belajar siswa yang awalnya $62,57 \%$ meningkat menjadi $81 \%$ dan partisipasi siswa didalam pembelajaran dari $62,7 \%$ meningkat menjadi 79,75\% (Jayadi, 2008).

Kenyataan yang ada di beberapa sekolah yang ada di Kabupaten Malang selama ini, proses refleksi belum dilakukan melalui jurnal belajar, refleksi hanya dilakukan setelah penyampaian materi selesai. Sebagaimana pernyataan salah satu guru Biologi SMP Muhammadiyah di Kabupaten Malang mengungkapkan bahwa selama ini belum pernah menggunakan jurnal belajar sebagai alat refleksi. Hal ini belum sesuia standar asesmen pembelajaran sains dewasa ini yang telah mengalami pergeseran penekanan dari "yang mudah dinilai" menjadi "yang penting untuk dinilai" (National Research Council/NRC, 1996). Asesmen hendaknya ditekankan pada penilaian kemampuan siswa dalam real life situation. Oleh sebab itu dibutuhkan tindakan untuk mengurangi masalah ini. Hal ini sebagaimana hasil penelitian oleh Morgan (2004) dalam Wulan (2007) dari The University of Texas menemukan bahwa lebih dari $70 \%$ guru tidak menggunakan rubrik dan portofolio dalam menilai pembelajaran.

Penggunaan jurnal belajar dapat melatih kemampuan berpikir siswa karena dalam penulisan jurnal siswa dituntut mengungkapkan apa yang ada dipikirannya. Kemampuan mengungkapkan apa yang ada dalam pikiran siswa ini merupakan salah satu pancaran dari karakterisitik siswa tersebut. Karakteristik merupakan satu variabel dari kondisi pengajaran, variabel ini didefinisikan sebagai aspek atau kualitas perseorangan. Aspek-aspek ini bisa berupa bakat, minat, sikap, motivasi belajar, gaya belajar, kemampuan berpikir, dan kemampuan awal dimiliki. Uraian tersebut mengungkapkan bahwa kemampuan berpikir siswa adalah salah satu variabel karakterisitik siswa dalam pengajaran termasuk pola berpikir kritis (Hamzah, 2009).

Kemampuan berpikir kritis setiap individu memiliki perbedaan dipengaruhi oleh pembinaann pendidikan maupun pembelajaran serta latar belakang individu. Hal ini memicu guru untuk mengetahui kemampuan berpikir kritis siswa yang tidak semua siswa mampu melakukan dengan baik. Berdasarkan masalah ini peneliti bermaksud untuk menggunakan jurnal belajar untuk melihat pengaruhnya terhadap berpikir kritis siswa. Indikator berpikir kritis mengacu pada lima kelompok indikator Ennis, yaitu (1) memberikan penjelasan sederhana (elementary clarification); (2) membangun keterampilan dasar (basic support); (3) membuat inferensi (infering); (4) membuat penjelasan lebih lanjut (advanced clarification); (5) mengatur strategi dan taktik (strategies and tactic) (Indrawati, 2012).

Berpikir kritis merupakan berpikir secara langsung terhadap sesuatu yang dituju atau sebagai kegiatan mengevaluasi dan mempertimbangkan kesimpulan yang akan diambil dari beberapa faktor pendukung untuk membuat keputusan. Proses tersebut dilalui setelah menentukan tujuan dan merupakan bentuk berpikir yang perlu dikembangkan dalam rangka memecahkan masalah, merumuskan kesimpulan, mengumpulkan berbagai kemungkinan, dan membuat keputusan ketika menggunakan semua keterampilan tersebut secara efektif dalam konteks dan tipe yang tepat (Indrawati, 2012). Oleh sebab itu, penulisan jurnal belajar sangat erat hubungannya dengan kemampuan berpikir kritis siswa karena apa yang akan ditulis siswa adalah hasil refleksi kegiatan belajarnya dan secara langsung dia tulis melalui proses berpikirnya.

Penulisan jurnal belajar diterapkan dalam pembelajaran Class Wide Peer Tutoring (CWPT) sebagaimana prosedur dasar yang terapkan oleh Greenwood. Adapun prosedur dasar CWPT yaitu: 1). meriview dan memperkenalkan materi yang 
akan dipelajari siswa, 2). memilih bahan yang akan dipelajari, 3). bagaimana kembali menetapkan mitra baru dalam setiap minggu, 4). bagaimana memilih strategi mitra pasangan, 5). bagaimana melaksanakan peran timbal balik pada setiap sesi, 6). bagaimana tim bersaing untuk titik tinggi tim, 7). bagaiman siswa mendapatkan poin individu, 8). Bagaimana tutor mengoreksi secara langsung, 9). cara mengirim nilai individu dan tim, dan 10). bagaimana menggunakan penghargaan sosial bagi tim pemenang.

Metode CWPT ini belum banyak dipakai meskipun memiliki banyak keuntungan dalam pembelajaran. Keuntungan pembelajaran CWPT yaitu: 1). mengharuskan siswa aktif dalam pembelajaran, 2). siswa mengembangkan bakat yang dimiliki, 3). Melatih siswa berpikir kritis, dan 4). siswa dapat memecah permasalahan-permasalahan yang ditemui (Hidayah, 2012). Alasan pembelajaran CWPT belum banyak diterapkan karena ketika pembelajaran guru tidak memantau seluruh kegiatan siswa, sehingga sering kali siswa tidak serius dalam kegiatan pembelajaran. Penggunaan refleksi pembelajaran yang mewajibkan siswa untuk membuat jurnal belajar disetiap akhir pembelajaran secara tidak langsung akan memotivasi siswa lebih bertanggung jawab terhadap pembelajaran, sehingga dapat meningkatkan pemahaman terhadap materi. Hal ini dapat berpengaruh terhadap kemampuan berpikir kritis siswa. Oleh sebab itu pembuatan jurnal belajar perlu dilakukan dalam pembelajaran CWPT.

Penelitian dilakukan di SMP Muhammadiyah di Kabupaten Malang materi fotosintesis kelas VIII dengan standar kompetensi 2. memahami sistem dalam kehidupan tumbuhan dan Kompetensi Dasar 2.2 mendeskripsikan proses perolehan nutrisi dan transformasi energi pada tumbuhan hijau. Alasan memilih materi fotosintesis supaya siswa lebih peka terhadap lingkungan alam sekitarnya. Siswa dapat mempelajari peristiwa-peristiwa alam sekitarnya khususnya tumbuhan yang mampu melakukan proses fotosintesis, sehingga siswa dapat mengetahui makhluk hidup yang dapat membuat makanan sendiri.

Tujuan yang hendak dicapai penelitian ini, yaitu 1) menganalisis pengaruh penggunaan jurnal belajar dalam pembelajaran Class Wide Peer Tutoring untuk meningkatkan kemampuan berpikir kritis siswa materi fotosintesis pada siswa kelas VIII SMP Muhammadiyah di Kabupaten Malang; 2) mendeskripsikan penerapan jurnal belajar dalam pembelajaran Class Wide Peer Tutoring mempengaruhi peningkatan kemampuan berpikir kritis materi fotosintesis pada siswa kelas VIII SMP Muhammadiyah di Kabupaten Malang; 3) mendeskripsikan peningkatan kemampuan berpikir kritis setelah perlakuan penggunaan jurnal belajar dalam pembelajaran Class Wide Peer Tutoring materi fotosintesis pada siswa kelas VIII SMP Muhammadiyah di Kabupaten Malang.

\section{METODE}

Penelitian dilaksanakan di SMP Muhammadiyah di Kabupaten Malang yaitu kelas VIII (SMP Muhammadiyah 04 Singosari, SMP Muhammadiyah 11 Pakis Aji, dan SMP Muhammadiyah 03 Kepanjen). Jenis penelitian dalam kegiatan ini adalah gabungan antara penelitian deskriptif dan penelitian Quasy Eksperimen Design yang dilakukan pada siswa kelas VIII di SMP Muhammadiyah Kabupaten Malang tahun pelajaran 2013/2014. Menurut Sugiyono (2010) disebut Quasy Eksperimen Design karena memiliki kelompok kontrol, tetapi tidak dapat berfungsi sepenuhnya untuk mengontrol variabel-variabel luar yangmempengaruhi pelaksanaan eksperimen. Ciri utama dari Quasy Eksperimen Design adalah sampel yang digunakan dalam untuk eksperimen maupun sebagai kelompok kontrol tidak dipilih secara random.

Populasi dalam penelitian ini adalah siswa kelas VIII SMP Muhammadiyah di 
Kabupaten Malang. Teknik pengambilan sampel yang digunakan adalah Cluster Random sampling, dengan pertimbangan populasi sangat luas dimana jumlah SMP Muhammadiyah di Kabupaten Malang yaitu 9 sekolah sehingga dilakukan randomisasi clauster. Sampel yang digunakan yaitu SMP Muhammadiyah 4 Singosari, SMP Muhammadiyah 03 Kepanjen, dan SMP Muhammadiyah 11 Pakis Aji. Adapun pengambilan sampel dari ketiga sekolah yaitu 48 siswa yang terdiri dari kelompok A (kelompok eksperimen) dan kelompok B (kelompok kontrol).

Variabel bebas dalam penelitian ini adalah penggunaan jurnal belajar. Variabel terikat yang digunakan dalam penelitian ini yaitu kemampuan berpikir kritis siswa. Variabel kontrol yaitu pembelajaran Class Wide Peer Tutoring (CWPT) pada siswa kelas VIII dan materi fotosintesis.

Metode yang digunakan untuk pengambilan data dalam penelitian ini menggunakan metode metode tes. Metode tes merupakan seperangkat pertanyaan dalam bentuk uraian untuk dijawab oleh siswa dalam mengukur kemampuan berpikir kritis siswa. Pemberian tes dilakukan sebelum dan sesudah pemberian treatmen (pretest/postest) untuk mengukur kemampuan awal dan akhir perlakuan. Hal ini dilakukan pada kelompok kontrol dan kelompok eksperimen, yaitu sebagai perbandingan hasil yang diperoleh dari kedua kelompok tersebut.

Penelitian dilakukan melalui beberapa tahapan, yaitu 1) Tahap persiapan penelitian, yaitu memberikan pengarahan pada guru kelas tentang pelaksanaan pembelajaran selama penelitian, yaitu tentang penggunaan pembelajaran Class Wide Peer Tutoring dan penggunaan jurnal belajar; 2) Membuat instrumen berupa tes uraian 20 soal untuk mengukur kemampuan berpikir kritis; 3) Membuat format bentuk jurnal belajar sebagai refleksi siswa; dan 4) Menyusun perangkat pelaksanaan pembelajaran (RPP) Class Wide Peer Tutoring (CWPT) materi fotosintesis.
Adapun pelaksanaan pembelajaran dalam penelitian ini, yaitu 1) Seluruh siswa di kelas dibagi dua kelompok dan diberika pretes. 2) Siswa dipasang-pasangkan menjadi tutor dan tutee yang duduk berdekatan, tutor dilengkapi naskah berisi materi akademik sesuai konten yang akan diajarkan. 3) Tutor mengajarkan satu bagian dari naskah kepada tutee dalam waktu tertentu, tutee merespon secara oral bagian yang diajarkan. 4) Tutor melakukan perhitungan poin berdasarkan jawaban yang diberikan tutee. 5) Kedua siswa bertukar peran saat waktu yang telah ditentukan habis. 6) Siswa yang berperan sebagai tutor (tutee) sekarang diajari oleh siswa yang berperan sebagai tutee (tutor) dalam waktu yang sama. 7) Pada setiap sesi tutoring guru mencatat perolehan poin setiap siswa. 8) Guru menjumlahkan seluruh perolehan poin yang dihasilkan oleh masing-masing tim. 9) Tim dengan perolehan poin terbanyak diumumkan sebagai pemenang dan diberi penghargaan berupa sticker oleh guru. 10) Guru memberikan lembar jurnal belajar yang telah disiapkan untuk diisi oleh siswa sebagai refleksi setelah mengikuti pembelajaran. 11) Guru memberikan postes untuk mengukur kemampuan berpikir kritis siswa setelah perlakuan

Teknik analisis data yang digunakan dalam penelitian ini adalah Uji Independent t-test, meliputi dua tahapan yang harus dilakukan yaitu Levene's test dan t-test.

\section{HASIL DAN PEMBAHASAN}

Hasil penelitian kemampuan berpikir kritis siswa dalam pembelajaran CWPT dengan penggunaan jurnal belajar yang telah dilakukan di SMP Muhammadiyah Kabupaten Malang (SMP Muhammadiyah 03 Kepanjen, SMP Muhammadiyah 04 Singosari, dan SMP Muhammadiyah 11 Pakisaji) pada tanggal 2-21 Mei 2014, disajikan pada Tabel 1.

Data Tabel 1 merupakan hasil postes dan pretes yang dilakukan pada siswa kelompok perlakuan maupun kelompok kontrol. 
Tabel 1. Data Skor Kemampuan Berpikir kritis Berbasis Kelompok Siswa

\begin{tabular}{|c|c|c|c|c|c|c|c|}
\hline \multicolumn{4}{|c|}{$\begin{array}{c}\text { Skor Berpikir Kritis } \\
\text { Kelompok Eksperimen }\end{array}$} & \multicolumn{4}{|c|}{$\begin{array}{l}\text { Skor Berpikir Kritis } \\
\text { Kelompok Kontrol }\end{array}$} \\
\hline $\begin{array}{l}\text { Kode } \\
\text { Siswa }\end{array}$ & $\begin{array}{l}\text { Sebelum } \\
\text { Perlakuan }\end{array}$ & $\begin{array}{l}\text { Sesudah } \\
\text { Perlakuan }\end{array}$ & $\begin{array}{l}\text { Selisih } \\
\text { Eksperimen }\end{array}$ & Kode Siswa & $\begin{array}{l}\text { Sebelum } \\
\text { Perlakuan }\end{array}$ & $\begin{array}{l}\text { Sesudah } \\
\text { Perlakuan }\end{array}$ & $\begin{array}{c}\text { Selisih } \\
\text { Kontrol }\end{array}$ \\
\hline $\mathrm{A} 01$ & 33 & 60 & 27 & B01 & 38 & 52 & 14 \\
\hline A02 & 40 & 67 & 27 & B02 & 46 & 53 & 7 \\
\hline $\mathrm{A} 03$ & 54 & 74 & 20 & B03 & 48 & 53 & 5 \\
\hline A04 & 56 & 67 & 11 & B04 & 47 & 53 & 6 \\
\hline A05 & 30 & 40 & 10 & B05 & 55 & 64 & 9 \\
\hline A06 & 32 & 60 & 28 & B06 & 37 & 44 & 7 \\
\hline A07 & 33 & 71 & 38 & B07 & 60 & 74 & 14 \\
\hline A08 & 27 & 53 & 26 & B08 & 45 & 54 & 9 \\
\hline A09 & 39 & 81 & 42 & B09 & 18 & 56 & 38 \\
\hline A10 & 26 & 86 & 60 & B10 & 32 & 63 & 31 \\
\hline A11 & 58 & 93 & 35 & B11 & 63 & 71 & 8 \\
\hline A12 & 25 & 77 & 52 & B12 & 41 & 53 & 12 \\
\hline A13 & 51 & 80 & 29 & B13 & 34 & 63 & 29 \\
\hline A14 & 43 & 90 & 47 & B14 & 14 & 47 & 33 \\
\hline A15 & 30 & 73 & 43 & B15 & 16 & 45 & 29 \\
\hline A16 & 44 & 77 & 33 & B16 & 28 & 34 & 6 \\
\hline A17 & 61 & 82 & 21 & B17 & 63 & 83 & 20 \\
\hline A18 & 63 & 78 & 15 & B18 & 37 & 66 & 29 \\
\hline A19 & 42 & 80 & 38 & B19 & 13 & 52 & 39 \\
\hline A20 & 27 & 54 & 27 & B20 & 45 & 46 & 1 \\
\hline A21 & 48 & 64 & 16 & B21 & 15 & 44 & 29 \\
\hline A22 & 46 & 61 & 15 & B22 & 38 & 44 & 6 \\
\hline A23 & 53 & 69 & 16 & B23 & 30 & 52 & 22 \\
\hline A24 & 34 & 46 & 12 & B24 & 32 & 37 & 5 \\
\hline Rata-rata & 41,45 & 70,12 & 28,67 & Rata-rata & 37,29 & 54,29 & 17 \\
\hline
\end{tabular}

Berdasarkan data hasil selisih skor protest dan pretest berpikir kritis, jumlah hasil selisih tertinggi terdapat pada kelompok perlakuan yaitu 60. Sementara kelompok kontrol sebesar 39. Adapun ratarata perlakuan yaitu 28,67 lebih besar dibandingkan kelompok kontrol yaitu 17 . Adapun data hasil berdasarkan indikator data Tabel 2 (Lihat Lampiran).

Tabel 2 merupakan ringkasan data hasil skor sebelum dan sesudah perlakuan berdasarkan indikator kemampuan berpikir kritis. Hasil data menunjukkan bahwa jumlah skor kelompok eksperimen sebelum dan sesudah perlakuan yaitu 12,42 (sebelum perlakuan) dan 19,78 (setelah perlakuan). Skor ini lebih tinggi dibanding kelompok kontrol yaitu 11,02 (sebelum pembelajaran) dan 15,59 (setelah pembelajaran) dengan perbedaan selisih 7,36 untuk kelompok perlakuan dan 4,57 untuk kelompok kontrol.

\section{Hasil Uji}

Adapun ringkasan data hasil uji kenormalan data menggunakan skewness (nilai kemiringan) dan kurtosis (titik kemiringan) dengan syarat nilai Skewness dan nilai kurtosis terletak diantara \pm 2 . Berdasarkan pengujian nilai skewness 1,51 dan nilai kurtosis -0,50 sehingga dapat disimpulkan bahwa data tersebut normal, kemudian data di uji t-test. Tahap pertama uji t-test adalah uji homogenitas atau uji levene test apabila probabilitas $>0,05$ maka $\mathrm{H}_{0}$ diterima, sementara apabila probabilitas $<0,05$ maka $\mathrm{H}_{0}$ ditolak. Hasil uji t-tes seperti pada Tabel 3 (Lihat Lampiran).

Sebelum dilakukan uji-t, terlebih dahulu dilakukan uji asumsi homogenitas dengan menggunakan levene's test. Hasil homogenitas menunjukkan nilai sig $>0,05$ berarti $\mathrm{H}_{0}$ diterima. Artinya, antara kedua kelompok memenuhi varians yang sama karena kedua varians sama maka uji-t yang digunakan adalah uji-t Pooled varians atau 


\section{Equal variances assumed.}

Hasil uji t-tes adalah sig $<0,05$ berarti $\mathrm{H}_{0}$ ditolak, maka terdapat perbedaan kemampuan berpikir kritis berdasarkan penggunaan jurnal belajar pada pembelajaran Class Wide Peer Tutoring (CWPT).

\section{Pengaruh Penggunaan Jurnal Belajar dalam Pembelajaran $C W P T$ Terhadap Peningkatan Kemampuan Berpikir Kritis Siswa}

Berdasarkan hasil analisis data dengan uji t-test dari selisih tertinggi pada perlakuan yaitu 60 sementara kontrol sebesar 39. Rata-rata skor kelompok perlakuan 28,67 sementara kontrol adalah 17 pada Tabel 4.1. Hasil uji t-test diperoleh nilai sig. $0,003<0,05$, ini menunjukkan bahwa penggunaan jurnal belajar dalam pembelajaran $C W P T$ berpengaruh terhadap kemampuan berpikir kritis siswa kelas VIII SMP Muhammadiyah Kabupaten Malang. Pengaruh penggunaan jurnal belajar terhadap kemampuan berpikir kritis siswa dapat dilihat pada Gambar 1.

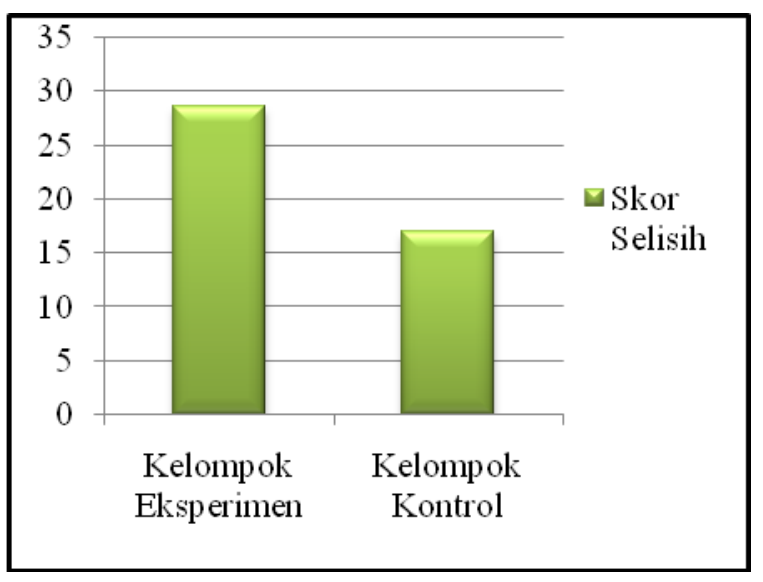

\section{Gambar 1. Diagram Kemampuan Berpikir kritis Berbasis kelompok siswa}

Berdasakan Gambar 1. dapat diketahui bahwa penggunaan jurnal belajar dapat memengaruhi kemampuan berpikir kritis siswa. Menurut (Fisher, 2008) berpikir kritis menuntut interpretasi dan evaluasi terhadap observasi, komunikasi, dan sumber-sumber informasi lainnya.
Penulisan jurnal belajar yang harus dibuat siswa menuntut mereka mengevaluasi dirinya dalam mengikuti kegiatan pembelajaran yakni sebagai refleksi diri setelah pembelajaran.

Jurnal belajar memiliki pengaruh terhadap kemampuan berpikir kritis siswa karena menulis jurnal belajar adalah kegiatan yang melatih siswa mengungkapkan tentang pemikiran mereka. Menulis adalah berpikir yang mendalam (berpikir kritis) dengan cara penemuan atau pengalaman, penyusunan urutan pengalaman, dan ketepatan pemilihan kata. Oleh karena itu kegiatan menulis menuntut keterlibatan penulis berpikir mendalam menemukan masalah yang disampaikan berupa gagasan dengan penataan dan penyusunan tulisan atau karangan yang padu agar pemikiran pembaca sama tepatnya dengan penulis (Zulkarnaini, 2011).

Bentuk refleksi yang berupa jurnal belajar berhubungan dengan cara pemikiran siswa dalam mengungkapkan pengalaman, pemahaman, dan penemuan yang disampaikan dalam bentuk tulisan. Menulis jurnal belajar membuat siswa harus peka terhadap apa yang telah dilakukan, didapat, dan apa yang ada dilingkungan sekitarnya khususnya pada saat pembelajaran. Hal tersebut sebagaimana yang dikemukakan Kartono \& Imron (2010) tentang tujuan penggunaan jurnal belajar. Tujuan penggunaan jurnal belajar diantaranya untuk memberi gambaran yang sesungguhnya mengenai pertumbuhan pemahaman dari suatu pengalaman seseorang dan menjaga rekaman pikiran dan ide seseorang melalui pengalaman belajarnya.

Proses berpikir yang terjadi pada diri siswa akan memudahkan dalam penulisan jurnal belajar dari hasil proses belajar yang dilakukan karena antara apa yang ditulis siswa merupakan hasil pemikiran mereka dari apa yang telah dialami. Hasil tulisan siswa dalam bentuk jurnal belajar adalah hasil pemikiran siswa sehingga penggunaan jurnal belajar ini 
memiliki pengaruh terhadap kemampuan berpikir kritis siswa. Sebagai salah satu dari aktivitas dari berpikir tingkat tinggi, berpikir kritis memainkan peranan penting dalam membangun kognisi seseorang karena berpikir kritis sebagai bagian dari sbuah proses aktif dimana seseorang memikirkan berbagai hal secara mendalam, mengajukan pertanyaan, menemukan informasi relevan daripada hanya menerima informasi secara pasif. Oleh karena itu, seseorang yang mempunyai kesulitan belajar akan berpikir cara menyelesaikan masalah tersebut berdasarkan fakta terjadi (Afandi, 2012).

Berpikir kritis memungkinkan siswa untuk menemukan kebenaran dari suatu informasi. Sebuah proses terorganisir yang memungkinkan siswa mengevaluasi bukti, asumsi logika, dan bahasa yang mendasari pernyataan orang lain terjadi dalam berpikir kritis dengan tujuan mencapai pemahaman yang mendalam. Pemahaman membuat siswa mengerti maksud di balik ide sehingga mengungkapkan makna dibalik suatu kejadian (Novikasari, 2009).

\section{Penerapan Jurnal Belajar dalam Pembelajaran CWPT untuk Meningkatkan Kemampuan Berpikir Kritis Siswa}

Berdasarkan analisis data hasil penelitian, didapatkan hasil bahwa terdapat pengaruh penggunaan jurnal belajar sebagai refleksi terhadap kemampuan berpikir kritis siswa. Penulisan jurnal belajar dilakukan oleh siswa setelah proses pembelajaran. Pembelajaran dalam penlitian ini adalah Class Wide Peer Tutoring sebagaimana menurut Hidayah et al (2012) mengemukakan bahwa pembelajaran ini mampu memperbaiki sikap siswa dalam proses pembelajaran karena pada sesi tutoring siswa dituntut untuk aktif baik berlaku sebagai tutor maupun tutee secara bergantian. Hal tersebut terlihat dari ratarata isi jurnal belajar yang ditulis siswa adalah tentang pengalaman belajar, materi yang dipahami, kesulitan belajar, upaya yang dilakuan dalam memahami materi yang belum dipahami selam belajar dikelas, dan ada juga yang berisi tentang keluhan yang mereka alami selama pembelajaran.

Berdasarkan hasil rata-rata nilai tertinggi terdapat pada pembelajaran Class Wide Peer Tutoring dengan penggunaan jurnal belajar. Pada pembelajaran ini hasil yang mereka dapatkan dalam evaluasi soal kemampuan berpikir kritis materi fotosintesis adalah dari hasil pengalaman belajar dan praktik penulisan jurnal yang mereka buat setelah mengikuti pembelajaran. Sedangkan, kelompok kontrol materi pelajaran diperoleh siswa sebagaimana hasil belajar mereka dengan berperan sebagai tutor-tutee serta dalam pembelajaran. Namun, pembelajaran Class Wide Peer Tutoring dengan penggunaan jurnal belajar lebih efektif digunakan untuk meningkatkan kemampuan berpikir kritis siswa dalam belajar. Pembelajaran ini sebelumnya pernah diterapkan oleh Afifah (2011) menunjukkan bahwa pembelajaran ini dapat meningkatkan KKM siswa.

Bentuk jurnal belajar yang ditulis siswa merupakan bentuk refleksi dari gagasan yang tercantum dalam pikiran siswa. Jadi, apa yang ada di pikiran siswa diluapkan dalam bentuk tulisan. Penulisan jurnal belajar dilakukan setelah pembelajaran CWPT dilaksanakan. Menurut Budiati (2009) menyatakan bahwa pembelajaran CWPT ini dapat mengubah secara efektif terhadap proses belajar dan hasil belajar siswa. Hal ini sesuai dengan hasil penelitian yang menunjukkan ada kaitan antara pembelajaran yang dilaksanakan dengan penggunaan jurnal belajaran sebagai refleksi terhadap kemampuan berpikir kritis.

Pembelajaran CWPT menuntut siswa memberikan dan menerima informasi antara siswa selama proses pembelajaran. Menurut Riyadi (2011) mengungkapkan individu memilih informasi secara langsung melalui sistem indera mereka, sehingga mereka menjadi lebih mahir dalam menerima dan merespons informasi yang datang. Prinsip-prinsip model pemrosesan informasi, pada dasarnya hampir sama 
dengan prinsip dalam teori stimulus dan respon. Teori proses pengolahan informasi berkaitan erat dengan tahapan saat seseorang menerima masukan dan memproses informasi menjadi rencana gerak dalam memorinya. Kemudian, proses adaptasi tampak pada mekanisme dari perencanaan gerak menjadi suatu unjukkerja keterampilan gerak seseorang.

Penggunaan jurnal belajar yang harus ditulis setelah pembelajaran CWPT khususnya materi fotosintesis dapat melatih siswa mengungkapkan pengalaman belajar mereka. Menurut King et al (2001) menyatakan bahwa penggunaan pembelajaran CWPT membuat interaksi sosial antara siswa di kelas melebar karena dalam pelaksanaannya guru harus menukar memabgi siswa berpasangan dan tiap pertemuan pasangan itu diganti. Tugas guru selebihnya menekankan siswa aktif dengan tim dalam meningkatkan kemenangan tim.

Jurnal belajar yang dibuat oleh siswa setelah pembelajaran ini sangat menekankan pada pengalaman belajar mereka sehingga guru dapar mengetahui seberapa pemahaman dan kesulitan belajar serta kondisi siswa pada saat pembelajaran. Hal ini berkaitan denga kemampuan berpikir kritis siswa karena proses berpikir mereka terasah ketika kegiatan pembelajaran berlangsung pada saat mereka berperan sebagai tutor-tutee secara bergantian. Seperti diungkapkan dalam hasil penelitian Indrawati (2012) bahwa terjadi peningkatan kemampuan berpikir krtis seseorang setelah kegiatan pembelajaran yang menekankan mereka aktif dalam kegiatan pembelajaran yang dilaksanakan.

\section{Peningkatan Kemampuan Berpikir Kritis Setelah Penggunaan Jurnal Belajar dalam Pembelajaran CWPT}

Berdasarkan data Tabel 2 kemampuan berpikir kritis berbasis indikator mengalami peningkatan setelah penggunaan jurnal belajar. Kemampuan berpikir kritis kelompok eksperimen berdasarkan indikator diperoleh selisih skor total 7,36. Sedangkan kelompok kontrol selisih skor total 4,57. Hal ini menunjukkan terjadi peningkatan kemampuan berpikir kritis dengan penggunaan jurnal belajar sebagai refleksi. Kemampuan berpikir kritis siswa kelompok eksperimen lebih efektif dibandingkan kelompok kontrol yang tidak menggunakan jurnal belajar sebagai refleksi. Peningkatan kemampuan berpikir kritis terjadi pada masing-masing indikator, sebagaimana terlihat pada selisih skor antara kelompok eksperimen dan kontrol. Peningkatan kemampuan berpikir kritis berbasis indikator seperti pada Gambar 2.

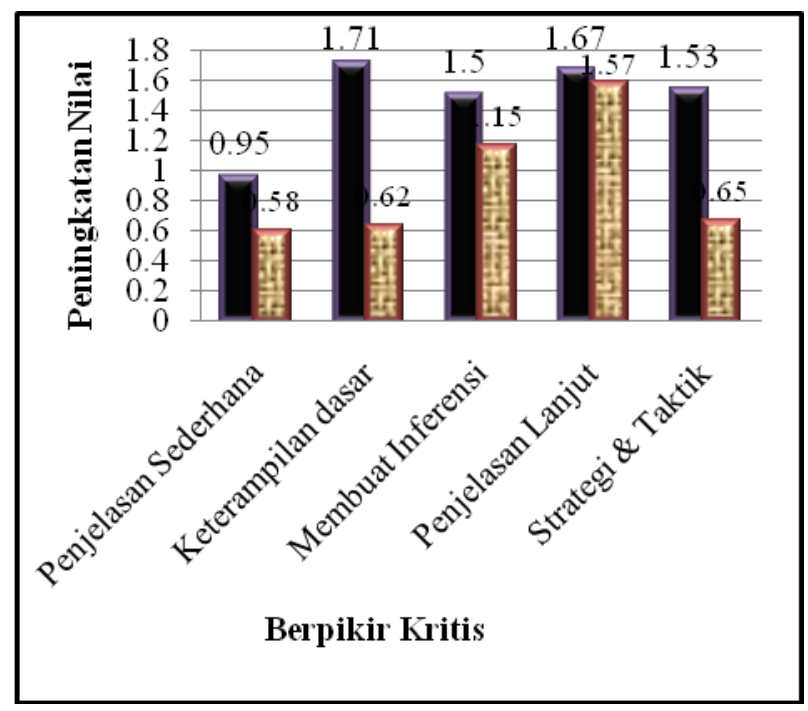

\section{Gambar 2. Diagram Peningkatan Kemampuan Berpikir Kritis Berbasis Indikator}

Gambar 2 menunjukkan adanya peningkatan kemampuan berpikir kritis terlihat dengan adanya selisih skor antara kelompok eksperimen dan kontrol pada setiap indikator yang digunakan untuk mengukur kemampuan berpikir kritis. Penggunaan jurnal belajar sebagai refleksi setelah pembelajaran dapat meningkatkan kemampuan berpikir kritis siswa.

Hal ini berdasarkan hasil evaluasi berupa soal esay berdasarkan selisih skor pada masing-masing indikator. Selisih skor terkecil terjadi pada indikator 4 , namun hal ini tetap menunjukkan bahwa peningkatan kemampuan berpikir kritis kelompok eksperimen lebih efektif daripada kontrol berdasarkan 4 indikator lainnya. 
Penulisan jurnal belajar yang dibuat siswa melibatkan kemampuan berpikirnya dalam menalarkan apa yang ada dibenak siswa dari apa yang mereka alami. Menurut Santrock (2009) berpikir melibatkan kegiatan manipulasi dan mentrasnformasi informasi dalam memori dan untuk membentuk konsep, menalar, berpikir kritis dan kreatif, membuat keputusan dan memecahkan masalah. Kemampuan berpikir kritis siswa dapat di ukur dengan pembelajaran yang menuntut siswa untuk aktif, memiliki peran, mengumpulkan dan menyampaikan informasi dan bertanggung jawab dalam pembelajaran serta penggunaan refleksi pembelajaran seperti jurnal belajar.

Peningkatan kemampuan berpikir kritis siswa terjadi setelah penggunaan jurnal belajar. Menurut Saefudin \& Kusumaningrum (2012) berpikir kritis merupakan suatu kemampuan untuk menganalisa fakta, mengorganisasi ide-ide, membuat kesimpulan, dan mengembangkan argumen. Hal ini menunjukkan bahwa ada keterkaitan antara penulisan jurnal belajar dengan perkembangan pemikiran seseorang terhadap apa yang dialami dan apa yang ada dibenak mereka. Sebagaimana pendapat Zulkarnaini (2011) bahwa menulis merupakan kemampuan berpikir kritis terkait penemuan dan penyususnan pengalaman serta ketepatan pemilihan kata. Penggunaan jurnal belajar sebagai refleksi dalam pembelajaran menjadi wadah bagi siswa menalarkan tentang apa yang ada dibenak mereka, apa yang dialami, dan melatih mereka untuk komunikatif dalam proses belajarnya.

Peningkatan kemampuan berpikir kritis secara terjadi pada siswa yang membuat refleksi berupa jurnal belajar karena menurut Santrock (2009), berpikir melibatkan kegiatan memanipulasi dan mentransformasi informasi dalam memori. Sedangkan, berpikir kritis meliputi berpikir secara reflektif dan produktif serta mengevaluasi bukti. Hal ini terjadi karena aktivitas berpikir kritis memainkan peranan penting dalam membangun kognisi seseorang. Berpikir kritis sebagai bagian dari sebuah proses aktif dimana seseorang berpikir mendalam dan menemukan informasi (Sunarno et al., 2012).

Penulisan jurnal belajar dapat membiasakan siswa mengevaluasi kemampuan mereka dalam belajar sehingga menjadikan mereka lebih bertanggung jawab dalam belajarnya. Darmawan (2010) menyatakan bahwa kemampuan berpikir kritis akan muncul dalam diri siswa apabila selama proses belajar di dalam kelas, guru membangun pola interaksi dan komunikasi yang lebih menekankan pada proses pembentukan pengetahuan secara aktif oleh siswa. Hal ini menunjukkan bahwa adanya pembelajaran CWPT dan penggunaan jurnal belajar setelah pembelajaran menjadi pendukung peningkatan kemampuan berpikir kritis siswa.

\section{KESIMPULAN DAN SARAN}

\section{Kesimpulan}

Berdasarkan penelitian pengaruh penggunaan jurnal belajar dalam pembelajaran Class Wide Peer Tutoring terhadap kemampuan berpikir kritis, hasil yang didapatkan adalah 1) Terdapat pengaruh penggunaan jurnal belajar dalam pembelajaran Class Wide Peer Tutoring terhadap kemampuan berpikir kritis materi fotosintesis pada siswa kelas VIII SMP Muhammadiyah di Kabupaten Malang. 2) Penerapan penggunaan jurnal belajar dilakukan setelah proses pembelajaran sebagai refleksi siswa setelah megikuti pembelajaran. 3) Peningkatan kemampuan berpikir kritis terjadi pada semua indikator dengan selisih skor total eksperimen 7,36 dan kontrol 4,57 sehingga eksperimen lebih efektif dalam meningkatkan kemampuan berpikir kritis daripada kontrol.

\section{Saran}

Dari hasil penelitian ini, penulis menyarankan 1) Adanya penelitian lanjutan penggunaan jurnal belajar dengan model pembelajaran lain dan materi Biologi 
lainnya. 2) Bagi guru bidang studi khususnya Biologi diharapkan menjadikan jurnal belajar sebagai salah satu alternatif penilaian terhadap siswa dan sebagai refleksi setiap pembelajaran.

\section{DAFTAR RUJUKAN}

Afifah, N. 2011. Strategi Pembelajaran Tutor Sebaya Untuk Meningkatkan Hasil Belajar Matematika Anak Berkesulitan Belajar Kelas IIIA SD Negeri Kepatihan Surakarta Tahun Pelajaran 2010/2011. Skripsi tidak diterbitkan. Surakarta: FKIP Universitas Sebelas Maret.

Budiati. 2009. Penerapan Model Pembelajaran Peer Mediated Instruction and Intervention (PMII) Tipe- Class wide Peer (CWPT) Dan teknik evaluasi Index Card Match Untuk Meningkatkan Kualitas Proses Dan Hasil Pembelajaran Biologi Kelas VII SMP Negert 22 Surakarta Tahun Pelajaran 2008/2009. Seminar Lokakarya Nasional Pendidikan Biologi FKIP UNS 18 Juli 2009. Surakarta.

Darmawan. 2010. Penggunaan Pembelajaran Berbasis Masalah dalam Meninkatkan Kemampuan Berpikir Kritis Siswa Pada Pembelajaran IPS di MI darussaadah pendeglang. Jurnal Penelitian Pendidikan, 11(2).

Fisher, A. 2008. Berpikir Kritis Sebuah Pengantar. Erlangga: Jakarta

Hamzah, B. 2009. Perencanaan Pembelajaran. Jakarta: Bumi Aksara.

Hidayah, E. N., Sajidan., \& Sugiharto, B. 2012. Penerapan Model Pembelajaran Class-Wide Peer Tutoring (Cwpt) Disertai Media Cergam Untuk Meningkatkan Kualitas Pembelajaran Biologi Siswa Kelas X 7 SMA Negeri 2 Sukoharjo Tahun Pelajaran 2011/2012. Jurnal Pendidikan Biologi, 4(2): 101-102.

Hidayah, E. N. 2012. Penerapan Model Pembelajaran Class-Wide Peer
Tutoring (CWPT) Disertai Media Cergam Untuk Meningkatkan Kualitas Pembelajaran Biologi Siswa Kelas X 7 SMA Negeri 2 Sukoharjo Tahun Pelajaran 2011/2012. Skripsi tidak diterbitkan. Surakarta: FKIP Universitas Sebelas Maret.

Indrawati, H. 2012. Meningkatkan Keterampilan Berpikir Kritis Mahasiswa Melalui Implementasi Model Controversial Issues Pada Mata Kuliah Ekonomi Sumberdaya Manusia dan Alam. Jurnal Pekbis, 4(1): 63-65.

Jayadi, Y. A. 2008. Penggunaan Jurnal Belaja dengan Macromedia Flash dalam Pembelajaran Biologi Untuk Meningkatkan Kualitas Pembelajaran Siswa Kelas X di SMA Negeri 2 Surakarta. Skripsi tidak diterbitkan. Surakarta: FKIP Universitas Sebelas Maret.

Junaedi, E. 2013. Penerapan Pembelajaran dengan Menggunakan Jurnal Belajar Untuk Meningkatkan Prestasi Belajar Bangun Ruang Pada Siswa SMP Negeri 10 Malang Kelas VIII-H. Malang: UM.

Kartono \& Imron, A. 2010. Penerapan Teknik Penilaian Learning Journal Pada Model Pembelajaran Berbasis Masalah untuk Meningkatkan Hasil Belajar Siswa Materi Pokok Segiempat. (Online), (http://journal. unnes.ac.id/nju/index.php/kreano/artic le/view/1246/1298, Diakses 13 November 2013).

King, K. dan Fulk, Barbara M. 2010. Classwide Peer Tutoring at work. Jurnal Teaching Exceptional Children, 34(2): 50.

Novikasari, I. 2009. Pengembangan Kemampuan Berpikir Kritis Siswa melalui Pembelajaran Matematika Open-ended di Sekolah Dasar. Jurnal Pemikiran Alternatif Kependidikan. 14(2).

Riyadi, S. 2011. Pemrosesan Informasi dalam Belajar Gerak. Jurnal Ilmiah Spirit, 11(2): 5-6 
Saefudin, A. A. \& Kusumaningrum, M 2012. Mengoptimalkan Kemampuan Berpikir Matematika Melalui Pemecahan Masalah Matematika. Seminar Nasional Matematika dan Pendidikan Matematika ISBN; 978-979.163538.7. Yogyakarta

Santrock, J. W. 2009. Psikologi Pendidikan Edisi 3: Jakarta: Salemba Humanika.

Sunarno, W., Sugiyarto., \& Afandi. 2012.

Pembelajaran Biologi Menggunakan Pendekatan Metakognitif Melalui Model Reciprocal Learning dan Problem Based Learning Ditinjau dari Kemamdirian Belajar dan Kemampuan Berpikir Kritis Mahasiswa. Jurnal Inkuiri, 2 (1).

Sutrisno, A. 2010. Upaya Meningkatkan Keterampilan Menulis Deskripsi
Melalui Pendekatan Contextual Teaching and Learning (CTL) Pada Siswa Kelas IV A SDN Dukuhan Kerten No. 58 Laweyan Surakarta. Skripsi tidak diterbitkan. Surakarta: FKIP Universitas Sebelas Maret.

Wulan. 2007. Penggunaan Asesmen Alternatif Pada Pembelajaran Biologi. Seminar Nasional Biologi: Perkembangan Biologi dan Pendidikan Biologi untuk Menunjang Profesionalisme Mei 2007 . Jakarta

Zulkarnaini, 2011. Model Kooperatif Tipe Think Talk Write (TTW) Untuk Meningkatkan Kemampuan Menulis Karangan Deskripsi dan Berpikir Kritis. Jurnal Edisi Khusus, No. 2, Agustus 2011.

\section{LAMPIRAN}

Tabel 2. Data Peningkatan Kemampuan Berpikir Kritis Berbasis Indikator

\begin{tabular}{|c|c|c|c|c|c|c|c|}
\hline \multirow{3}{*}{$\begin{array}{c}\text { Indikator Berpikir } \\
\text { Kritis }\end{array}$} & \multicolumn{4}{|c|}{ Kelompok Eksperimen } & \multicolumn{3}{|c|}{ Kelompok Kontrol } \\
\hline & \multirow[t]{2}{*}{ No. Item } & \multicolumn{2}{|c|}{ Skor } & \multirow[t]{2}{*}{ Selisih } & \multicolumn{2}{|c|}{ Skor } & \multirow[t]{2}{*}{ Selisih } \\
\hline & & Sebelum & Sesudah & & Sebelum & Sesudah & \\
\hline $\begin{array}{l}\text { Memberikan } \\
\text { penjelasan sederhana }\end{array}$ & $\begin{array}{l}1,2 \\
5,12\end{array}$ & 3,19 & 4,14 & 0,95 & 2,97 & 3,55 & 0,58 \\
\hline $\begin{array}{l}\text { Membangun } \\
\text { keterampilan dasar }\end{array}$ & 6,17 & 2,37 & 4,08 & 1,71 & 2,1 & 2,72 & 0,62 \\
\hline Membuat inferensi & $3,4,9,11,13$ & 2,86 & 4,36 & 1,5 & 2,74 & 3,89 & 1,15 \\
\hline $\begin{array}{l}\text { Membuat penjelasan } \\
\text { lebih lanjut }\end{array}$ & 7,10 & 1,95 & 3,62 & 1,67 & 1,28 & 2,85 & 1,57 \\
\hline $\begin{array}{l}\text { Mengatur strategi dan } \\
\text { taktiK }\end{array}$ & $\begin{array}{c}8,14,15,16 \\
18,19,20\end{array}$ & 2,05 & 3,58 & 1,53 & 1,93 & 2,58 & 0,65 \\
\hline JUMLAI & & 12,42 & 19,78 & 7,36 & 11,02 & 15,59 & 4,57 \\
\hline
\end{tabular}

Tabel 3. Ringkasan Uji t-test Berpikir Kritis Siwa

\begin{tabular}{|c|c|c|c|c|c|c|c|}
\hline & & \multicolumn{2}{|c|}{$\begin{array}{c}\text { Levene's Test for } \\
\text { Equality of Variances } \\
\end{array}$} & \multicolumn{4}{|c|}{ t-test For Equality Of Means } \\
\hline & & $\mathbf{F}$ & Sig. & $\mathbf{t}$ & df & Sig.(2-tailed) & $\begin{array}{c}\text { Mean } \\
\text { Difference }\end{array}$ \\
\hline \multirow{2}{*}{$\begin{array}{l}\text { Hasil tes } \\
\text { kemampuan } \\
\text { berpikir kritis }\end{array}$} & $\begin{array}{l}\text { Equal } \\
\text { variances } \\
\text { assumed }\end{array}$ & ,003 & ,954 & 3,14 & 46 & ,003 & 11,67 \\
\hline & $\begin{array}{l}\text { Equal } \\
\text { variances } \\
\text { not assumed }\end{array}$ & & & 3,14 & 45,34 & ,003 & 11,67 \\
\hline
\end{tabular}

